\title{
Effect of gamma rays on the bone repair process in rats with estrogen deficiency
}

\author{
Efeito da radiação gama no processo de \\ reparo ósseo em ratas com deficiência de \\ estrógeno
}

\author{
Mariliani Chicarelli(a) \\ Flávia Maria de Moraes Ramos ${ }^{(b)}$ \\ Flávio Ricardo Manzi(a) \\ Pedro Duarte Novaes ${ }^{(c)}$ \\ Frab Norberto Bóscolo(a) \\ Solange Maria de Almeida ${ }^{(a)}$
}

(a) PhDs, Oral Radiology; (b) MSc, Oral Radiology; (c)PhD, Histology - School of Dentistry of Piracicaba, State University of Campinas.

\section{Corresponding author:}

Flávia Maria de Moraes Ramos

Universidade de Campinas

Faculdade de Odontologia de Piracicaba -

Radiologia Oral

Av. Limeira, 901 - Cx. Postal 52

Piracicaba - SP - Brazil

CEP: 13414-018

E-mail: flaviamaria@fop.unicamp.br

\begin{abstract}
This study aimed at evaluating the bone repair process in ovariectomized rats submitted to an irradiation procedure. For this purpose, one hundred rats were randomly divided in four experimental groups: control, ovariectomized, irradiated and irradiated/ ovariectomized. A bone defect was made on all animals' tibias. Three days after surgery, only irradiated and irradiated/ovariectomized rats received 8 Gy of gamma rays on the lower limbs region. The animals were sacrificed 7, 14, 21 and 28 days after surgery in order to assess the repair process. It was possible to observe a delay in the bone repair process in the irradiated/ovariectomized group, in which there was a remarkable association between estrogen deficiency and ionizing radiation resulting in the reduction of newly formed bone production, thus accelerating the resorption process.
\end{abstract}

Descriptors: Estrogens; Osteoporosis; Ovariectomy; Bone and bones; Fracture healing.

Resumo: O objetivo deste trabalho foi avaliar o processo de reparo ósseo em ratas ovariectomizadas submetidas ao procedimento de irradiação. Para isto, cem ratas foram aleatoriamente divididas em quatro grupos experimentais: controle, ovariectomizado, irradiado e ovariectomizado/irradiado. Um defeito ósseo foi confeccionado nas tíbias de todos os animais. Três dias após a cirurgia, apenas os animais pertencentes aos grupos irradiado e ovariectomizado/irradiado receberam 8 Gy de radiação gama na região dos membros inferiores. Os animais foram sacrificados 7, 14, 21 e 28 dias após a cirurgia. Foi possível observar um atraso no processo de reparo ósseo nos animais do grupo ovariectomizado/irradiado, no qual houve uma marcante associação entre deficiência de estrógeno e radiação ionizante, resultando na redução da produção de osso neoformado, acelerando o processo de reabsorção.

Descritores: Estrogênios; Osteoporose; Ovariectomia; Osso e ossos; Consolidação da fratura. 


\section{Introduction}

The ovary is the major source of estrogen, and ovarian function loss results in the reduction of the endocrine hormones that maintain skeletal mass. ${ }^{12}$ Estrogen is involved in the bone remodeling process, being responsible for the balance between resorption and bone formation. The rat skeleton is a widely used model in preclinical research on osteoporosis. ${ }^{17}$ Ovariectomy is associated with similar histological changes in rat bones and in human bones, and it can thus provide beneficial information related to human postmenopausal bone loss. However, there are differences between the rodent and human skeletons, so care is necessary in order to prevent misunderstanding. ${ }^{4,8}$

Malignant lesions are mainly treated by the association of surgical and radiographic procedures. ${ }^{2}$ Ionizing radiation is largely used for diagnostic and therapeutic purposes, but its application often results in deleterious effects. ${ }^{1}$ Thus, trauma healing may be compromised in irradiated and fragile bones. So, the adverse effect resulting from estrogen deficiency, caused by either postmenopausal or surgical procedures, is very concerning. The aim of this study was to evaluate the bone repair process in ovariectomized rats submitted to an irradiation procedure.

\section{Material and Methods}

One hundred female Wistar adult rats were used and randomly divided in four experimental groups $(\mathrm{n}=5)$ : control, comprising sham-operated animals; ovariectomized, on which bilateral ovariectomies were performed; irradiated, where the animals were irradiated and sham operated; irradiated/ovariectomized, on which bilateral ovariectomies were performed before the irradiation procedure. Ovariectomy success was evaluated by examining the estrous cycle $^{14}$ two weeks after the surgical procedure and observing the marked atrophy of the uterine horns in the ovariectomized rats. Forty-six days after the ovariectomy and sham-ovariectomy, the animals were weighed and anesthetized by an intramuscular injection of ketamin chlorhydrate $(0.1 \mathrm{mg} / \mathrm{kg})$ in order to create a bone defect on the tibia. For this, a borehole was drilled into the tibia cortical bone using a number- 6 carbide bur (KG Sorensen, São Paulo, São Paulo, Brazil). Three days after the bone defect proce- dure, the animals were anesthetized once more with the same drug, and the rats belonging to the irradiated and irradiated-ovariectomized groups received, in the lower limbs region, a single acute exposure of 8 Gy $\left(\mathrm{Co}^{60}\right.$, Alcion CGR II, Siemens, São Paulo, São Paulo, Brazil) at $80 \mathrm{~cm} .{ }^{6}$ Control and ovariectomized animals were anesthetized, but not irradiated. The irradiation field corresponded to $31 \mathrm{x} 16 \mathrm{~cm}$.

The specimens were obtained 7, 14, 21 and 28 days after the bone defect surgery. The removed tibias were placed in $10 \%$ formaldehyde buffer for 72 hours. The bone specimens were then dehydrated in 5\% EDTA (Titriplex III, ACS, ISO, Merck, Darmstadt, Germany) embedded in paraffin, longitudinally sectioned ( $6 \mu \mathrm{m}$ thick) and stained with Picrosirius for birefringence analysis. A polarized light microscopy (10 X) (Zeiss, Axiolab, Berlin, Germany) and a micro camera (Sony, CCD/RGB Color, Tokyo, Japan) for image digitalization were used. By using an analytical system (KS 400 2.0-Kontron Elektronics, Munich, Germany), three measures $\left(\mathrm{cm}^{2}\right)$ were made, one of which was in the middle of the bone defect and the others beside it, under the cortical bone. Data were initially evaluated using ANOVA. Significant differences were resolved by the Tukey test, with a significant $\mathrm{p}$-value $<0.05$.

In order to assess the volumetric density, in $\mathrm{mm}^{3} /$ $\mathrm{mm}^{3}$, of the bone surface, two measures were made in different areas and observed with a light microscope $(10 \mathrm{X})$, using a reticulum with 100 points, each of which was equal to $0.065 \mathrm{~mm}^{3}$. Next, bone volumetric density was calculated by the formula

$$
\begin{aligned}
& \mathrm{Vv}=\mathrm{P} \times(0.065)^{3} / 100 \times(0.065)^{3} \mathrm{~mm}^{3} / \mathrm{mm}^{3}, \\
& \text { where: } \\
& \mathrm{Vv}=\text { volumetric density; } \\
& \mathrm{P}=\text { number of impact points. }
\end{aligned}
$$

The results were submitted to ANOVA $(\mathrm{p}<0.05)$ for the groups in the experimental periods.

\section{Results Quantitative evaluation of the collagen fibers area by Picrosirius staining}

At 7 days, it was possible to observe that the control (sham-I) and ovariectomized (II) groups 
presented greater birefringence values which were statistically different from those in the irradiated (III) and ovariectomized/irradiated (IV) groups. The ovariectomized/irradiated group presented the lowest values, differing statistically from the other three groups (Table 1). After 14 days of the repair process, the greatest mean was seen in the control, irradiated, ovariectomized and ovariectomized/irradiated groups, respectively (Table 1). At 21 days, the highest birefringence mean was found in the irradiated group. No significant differences were observed between the control and irradiated groups or between the ovariectomized and ovariectomized/irradiated groups, but statistical differences were found between the irradiated and ovariectomized/irradiated groups (Table 1). At 28 days of the repair process, the ovariectomized and ovariectomized/irradiated groups presented the lowest values, which were not significantly different from each other; however, differences were found in relation to the control and irradiated groups (Table 1).

\section{Quantitative evaluation of volumetric density}

At 7 days, it was possible to observe that the control group presented the highest value, which was followed by that of the ovariectomy (II) group, and no significant differences were observed between those groups at that time. The irradiated and ovari-

Table 1 - Means and standard deviations of the area $\left(\mathrm{cm}^{2}\right)$ of birefringent bone organic matrix at $7,14,21$ and 28 days of the repair process.

\begin{tabular}{|c|c|c|c|}
\hline Time & & Non-irradiated & Irradiated \\
\hline \multirow{2}{*}{7 days } & Sham & $66.6(16.20) \mathrm{Aa}$ & 39.5 (8.30) Ba \\
\hline & Ovariectomized & $65.4(12.30) \mathrm{Aa}$ & $16.4(6.60) \mathrm{Bb}$ \\
\hline \multirow{2}{*}{14 days } & Sham & $23.3(10.00) \mathrm{Aa}$ & $20.5(4.60) \mathrm{Ba}$ \\
\hline & Ovariectomized & 17.9 (3.40) Ab & $7.5(2.01) \mathrm{Bb}$ \\
\hline \multirow{2}{*}{21 days } & Sham & $15.4(11.30) \mathrm{Aa}$ & 15.9 (5.90) Aa \\
\hline & Ovariectomized & $9.5 \quad(2.30) \mathrm{Ab}$ & $5.7 \quad(2.60) \mathrm{Ab}$ \\
\hline \multirow{2}{*}{28 days } & Sham & $15.1 \quad(4.00) \mathrm{Aa}$ & $10.7(5.00) \mathrm{Aa}$ \\
\hline & Ovariectomized & $1.4 \quad(0.50) \mathrm{Ab}$ & $0.9 \quad(0.40) \mathrm{Ab}$ \\
\hline
\end{tabular}

* Means followed by different lower case letters in the same column and capital letters in the same line, for each time, differ statistically, with a significant $p$-value of $5 \%$, by the Tukey test. ectomized/irradiated (IV) groups showed the lowest values, but no statistical difference between them was found. However, comparing the control group with the irradiated group and the ovariectomized group with the ovariectomized/irradiated group, statistical differences were observed (Table 2). After 14 days, the groups presenting the lowest values were the ovariectomized/irradiated and ovariectomized groups, followed by the sham (control) and irradiated groups. Statistical differences were found between the sham (control) and ovariectomized groups and between the irradiated and ovariectomized/irradiated groups (Table 2). At 21 days, the control group continued presenting the highest volumetric density value, statistically different from that of the ovariectomized group. The ovariectomized/irradiated group showed the lowest value, and statistical differences were observed when comparing it with the irradiated and sham group (control) (Table 2). At 28 days of the repair process, the ovariectomized/irradiated group presented the lowest volumetric bone density, and such value was not statistically different from that of the ovariectomized group, but statistically different in relation to that of the irradiated group. Additionally, the highest mean was observed in the sham (control) group (Table 2).

The relationship between birefringence and volumetric density is directly proportional. A greater value of birefringence means more collagen fibers

Table 2 - Means and standard deviations of the volumetric density $\left(\mathrm{mm}^{3} / \mathrm{mm}^{3}\right)$ in the bone tissue at $7,14,21$ and 28 days of the repair process.

\begin{tabular}{|c|c|c|c|}
\hline Time & & Non-irradiated & Irradiated \\
\hline \multirow{2}{*}{7 days } & Sham & $0.36(0.09) \mathrm{Aa}$ & $0.14 \quad(0.050) \mathrm{Ba}$ \\
\hline & Ovariectomized & $0.26(0.09) \mathrm{Aa}$ & $0.13(0.080) \mathrm{Ba}$ \\
\hline \multirow{2}{*}{14 days } & Sham & $0.21(0.07) \mathrm{Aa}$ & $0.22 \quad(0.040) \mathrm{Aa}$ \\
\hline & Ovariectomized & $0.19(0.06) \mathrm{Ab}$ & $0.11 \quad(0.040) \mathrm{Ab}$ \\
\hline \multirow{2}{*}{21 days } & Sham & $0.20(0.01) \mathrm{Aa}$ & $0.17 \quad(0.010) \mathrm{Aa}$ \\
\hline & Ovariectomized & $0.05(0.05) \mathrm{Ab}$ & $0.03 \quad(0.010) \mathrm{Ab}$ \\
\hline \multirow{2}{*}{28 days } & Sham & $0.20(0.03) \mathrm{Aa}$ & $0.09 \quad(0.060) \mathrm{Ba}$ \\
\hline & Ovariectomized & $0.01(0.01) \mathrm{Ab}$ & $0.004(0.003) \mathrm{Ab}$ \\
\hline
\end{tabular}

*Means followed by different lower case letters in the same column and capital letters in the same line, for each time, differ statistically, with a significant $p$-value of $5 \%$, by the Tukey test. 
and consequently greater values of bone trabeculae, which is represented by values of volumetric density. Thus, in all periods of the study, the groups that presented the highest values of birefringence also showed the major values of volumetric density.

\section{Discussion}

The bone remodeling function is always in balance and depends on systemic and local factors. Amongst systemic factors, estrogen is probably the most important hormone responsible for the maintenance of normal bone turnover. ${ }^{18}$ Bone fracture and some surgical procedures cause a modification in tissue integrity; therefore, good healing is necessary in order for this tissue to exert its normal activities. In this study, it was possible to observe that some systemic and local factors, such as estrogen deficiency and ionizing radiation, respectively, negatively influenced the bone repair process, since the group that received these two variables, presented the most damage. According to Meyer et al..$^{15}$ (2001), the bone remodeling process can also suffer the influence from systemic and local factors.

Women are more commonly affected by osteoporosis. Severe bone loss is related to the acute effect of estrogen deficiency and aging factors, both contributing to increase bone fragility. ${ }^{7}$ Lill et al. ${ }^{13}$ (2002) are consistent when affirming that there are few available studies on the differences between the bone repair process in healthy individuals and in those presenting osteoporosis as they apparently presented a diminished capacity of repairing and remodeling.

The loss of ovarian function in animals and humans causes dramatic and accelerated bone loss. ${ }^{11}$ According to Peng et al. ${ }^{17}$ (1997), ovariectomy in animals is associated with similar histological changes in rat bones as well as in human bones, and this model of study provides favorable information related to human bone loss.

Ionizing radiation is frequently used for the treatment of primary or metastatic bone malignancies. The real mechanism involved with its action in bones is still not fully understood; however, recent studies have demonstrated that radiation modifies the balance between osteoclastic and osteoblastic activity, favoring the destructive process. ${ }^{6,20}$ Nowa- days, it is not uncommon for people with osteoporosis to require diagnostic exams or therapeutic treatments using ionizing radiation. According to Gal et al. ${ }^{9}$ (2000), osteoblast proliferation is inhibited by radiation since there is an attenuated growth rate in irradiated cells, and osteoblasts show diminished rates of collagen production. Thus, this study aimed at evaluating the bone repair process resulting from the association of two variables: ionizing radiation and estrogen deficiency.

Irradiation delivered three days after a surgery procedure was chosen according to Raveli et al. ${ }^{19}$ (1990), since the period immediately after surgery is one of the most critical among the repair process phases, and radiation may cause severe alterations in bone and in its capacity to react to trauma.

When bone integrity is breached, a cellular and biochemical sequence of events occurs, inducing inflammatory reactions. In mechanically steady areas, such as that of the bone defects produced in the animals in this study, or in cavities of stable fractures, the wound is newly vascularized and osteoblasts proliferate, thus forming bone. In this study, it was possible to observe that, in the control group, no modified factors interfered with the bone healing progress, as the defect was a mechanically steady area. In the ovariectomized group, the repair process development was less evident in relation to that in the control group. Volumetric density showed that the bone repair progress in the ovariectomized group was similar in relation to that of the control group at 7 days; therefore, there was no statistically significant difference. This difference was significant at 14 , 21 and 28 days, when there was a decline in volumetric density. In relation to birefringence, it also presented a statistically significant difference at 14 , 21 and 28 days, showing a decline in collagen fibers conforming to the progress of the repair process.

Tanaka et al. ${ }^{22}$ (2001) reported that acute estrogen deficiency stimulated the supporting bone, having less influence on bone formation, which justifies a delay in the repair process. Chow et al. ${ }^{3}$ (1992) stated that estrogen maintained bone mass, not only through bone resorption inhibition, but also stimulating its formation. This coincides with the findings of Danielsen et al. ${ }^{4}$ (1993), who claimed that estro- 
gen treatment interrupted the endosteal bone resorption. Other authors ${ }^{16,21}$ also reported trabecular bone loss in animals submitted to a surgical ovariectomy procedure.

In the irradiated group, the repair process was incipient, especially in relation to that of the control group. Volumetric density was statistically different between the control and irradiated groups at 7 and 28 days. The irradiated/ovariectomized group presented fewer bone trabeculae when compared to the irradiated group, a difference which was statistically significant from the $14^{\text {th }}$ day on. Comparing with the control group, birefringence showed that the irradiated group presented less birefringence at 7 and 14 days, thus explaining the slighter tissue maturation level. However, in relation to the irradiated/ovariectomized group, the birefringence mean of the irradiated group was always greater, and statistically different at all evaluation times in this study. Thus, although the real mechanism of bone damage by ionizing radiation is still not clear, there is a corroboration that the balance between resorption and bone formation is altered, and resorption events prevail. According to Hayashi, Suit ${ }^{10}$ (1971), the delayed bone healing process could be related to a minor subgroup of cells that present low repairing capacity resulting from radiation damage. The decrease of osteocytes and osteoblasts or the absence of osteoblasts on the bone surface leads to a decline in collagen synthesis and alkaline phosphatasis activity, consequently hindering the mineralization process and increasing bone resorption, which could result in spontaneous fractures. ${ }^{2,6,20}$ Dare et al..$^{5}$ (1997) stated that high radiation doses, such as $4 \mathrm{~Gy}$, could exert a different effect on cellular proliferation and osteoblast dedifferentiation, which explains the results obtained in this study,

\section{References}

1. Almeida SM, Ferreira RI, Bóscolo FN. Influence of irradiation on collagen content during wound healing in diabetic rats. Pesqui Odontol Bras. 2002;16(4):293-8.

2. Arnold M, Stas P, Kummermehr J, Schultz-Hector S, Trott KR. Radiation-induced impairment of bone healing in the rat femur: effects of radiation dose, sequence and interval between since a radiation dose of 8 Gy was used. With the exception of the control group, trabeculae bone formation was delayed, and an interesting result was observed: bone resorption occurred before total tissue formation, especially in the ovariectomized and irradiated/ovariectomized groups. It is supposed that radiation affects the beginning of bone formation and estrogen deficiency accelerates the bone resorption process. Besides, we believe that radiation promotes a more accelerated resorption process in the final repair phase. Therefore, as the irradiated/ ovariectomized group received an association of the two factors, estrogen deficiency and ionizing radiation, there was slight bone trabeculae formation and less tissue maturation at the beginning of the repair process following the application of such two variables, and, from 14 days on, there was accentuated resorption of the fewer and immature bone trabeculae present. Wang ${ }^{23}$ (2000) claimed that the threedimensional space orientation of the osteons in the normal repair process was not completely reestablished. This effect may be accentuated due to other factors, such as estrogen deficiency and radiation, thus altering the repair process or tissue organization, which could result in more accentuated bone resorption of the newly formed bone.

\section{Conclusion}

Based on the experimental conditions and on the results observed in this study, it is possible to conclude that, in the irradiated/ovariectomized rats, the morphological and structural analyses of the newly formed bone indicated a delay in the repair process and the association between estrogen deficiency and radiation resulted in a decrease in the production of the newly formed bone, thus accelerating the resorption process.

surgery and irradiation. Radiother Oncol. 1998;48(3):25965.

3. Chow J, Tobias JH, Colston KW, Chambers TJ. Estrogen maintains trabecular bone volume in rats not only by suppression of bone resorption but also by stimulation of bone formation. J Clin Invest. 1992;89(1):74-8. 
4. Danielsen CC, Mosekilde L, Svenstrup B. Cortical bone mass, composition, and mechanical properties in female rats in relation to age, long-term ovariectomy and estrogen substitution. Calcif Tissue Int. 1993;52(1):26-33.

5. Dare A, Hachisu R, Yamaguchi A, Yokose S, Yoshihi S, Okano $\mathrm{T}$. Effects of ionizing radiation on proliferation and differentiation of osteoblast-like cells. J Dent Res. 1997;76(2):65864.

6. Dudziak ME, Saadeh PB, Mehrara BJ, Steinbrech DS, Greenwald JA, Gittes GK et al. The effects of ionizing radiation on osteoblast-like cells in vitro. Plast Reconstr Surg. 2000;106(5):1049-61.

7. Eastell R. Management of osteoporosis due to ovarian failure. Med Pediatr Oncol. 2003;41(3):222-7.

8. Frost HM, Jee WSS. On the rat model of human osteopenias and osteoporoses. Bone Miner. 1992;18(3):227-36.

9. Gal TJ, Munoz-Antonia T, Muro-Cacho CA, Klotch DW. Radiation effects on osteoblasts in vitro. Arch Otolaryngol Head Neck Surg. 2000;126(9):1124-8.

10. Hayashi S, Suit HD. Effect of fractionation of radiation dose on callus formation at site of fracture. Radiology. 1971;101(1):181-6.

11. Jilka RL, Hangoc G, Girasole G, Passeri G, Willians DC, Abrams JS. Increased osteoclast development after estrogen loss: mediation by interleukin-6. Science. 1992;257(3):8891.

12. Lane NE, Thompson JM, Haupt D, Kimmel DB, Modin G, Kinney JH. Acute changes in trabecular bone connectivity and osteoclast activity in the ovariectomized rat in vivo. J Bone Miner Res. 1998;13(2):229-36.

13. Lill CA, Fluegel AK, Schneider E. Effect of ovariectomy, malnutrition and glucocorticoid application on bone properties in sheep: A pilot study. Osteoporos Int. 2002;13(6):480-6.
14. Marcondes FK, Bianchi FJ, Tanno AP. Determination of the estrous cycle phases of rats: Some helpful considerations. Braz J Biol. 2002;62(4):609-14.

15. Meyer RA Jr, Tsahakis PJ, Martin DF, Banks DM, Harrow ME, Kiebzak GM. Age and ovariectomy impair both the normalization of mechanical properties and the accretion of mineral by the fracture callus in rats. J Orthop Res. 2001;19(3):428-35.

16. Miller SC, Wronski TJ. Long-term osteopenic changes in cancellous bone structure in ovariectomized rats. Anat Rec. 1993;236(3):433-41.

17. Peng ZQ, Väänänen HK, Zhang HX. Long-term effects of ovariectomy on the mechanical properties and chemical composition of rat bone. Bone. 1997;20(3):207-12.

18. Raisz LG. Physiology and pathophysiology of bone remodeling. Clin Chem. 1999;45(8):1353-8.

19. Raveli D, Ferreira B, Cordeiro R, Okamoto T, Gabrielli M. Influência da radiação $\mathrm{X}$ na cronologia do processo de reparo em feridas de extração dental. Estudo histomorfológico em ratos. Rev Odontol Univ São Paulo. 1990;4:119-25.

20. Szymczyk KH, Shapiro IM, Adams CS. Ionizing radiation sensitizes bone cells to apoptosis. Bone. 2004;34(1):148-56.

21. Tanaka M, Toyooka E, Kohno S, Ozawa H, Ejiri S. Longterm changes in trabecular structure of aged rat alveolar bone after ovariectomy. Oral Surg Oral Med Oral Pathol. 2003;95(4):495-502.

22. Tanaka S, Shimizu M, Debari K, Furuya R, Kawawa T, Sasaki T. Acute effects of ovariectomy on wound healing of alveolar bone after maxillary molar extraction in aged rats. Anat Rec. 2001;262(2):203-12.

23. Wang J. Spatial orientation of the microscopic elements of cortical repair bone. Clin Orthop Relat Res. 2000;374:26577. 